\title{
EFFECTIVENESS OF SIGHT WORDS \& DOMINO STRATEGIES IN TEACHING NEW VOCABULARY TO ENHANCE READING ABILITY AMONG LOW LITERACY YEAR TWO PUPILS
}

\author{
${ }^{1}$ Bitty Ansawi \\ May O Mail \\ Martina Miasin². \\ Tuaran Education Office, Sabah, MALAYSIA \\ Sekolah Kebangsaan Selupoh Tuaran, Sabah, MALAYSIA
}

\begin{abstract}
Vocabulary and pronunciation learning is an important and indispensable part of any language learning process. Children's lack of vocabulary and incorrect pronunciation caused them to encounter difficulty in learning to read. This led them lost interest in learning this first world language. Despite this concerning issues, many schools has yet implementing effective method of teaching English. The main objective of this study is to propose a relational model between scaffolding strategy, students learning participation, students' vocabulary, and academic performances. This article will use descriptive quantitative survey method in SK Selupoh, Tuaran in Sabah, Malaysia. The study will measure the impact of using sight word and Domino strategy toward students' English learning performance. The study will be carried out in six phases; Identification \& Selection of Trainees, Discussion and Knowledge Sharing, Coaching and Modeling, Selecting the Target Students, Implementing the Intervention Program, Evaluation and Further Action.The research will based on an empirical study with quantitative measures to determine the inter-relationships between scaffolding strategy, vocabulary level, students participation and students' learning performance. The findings from this study may benefit other mainstream teachers in English teaching thus greatly assist English language learners in their journey of language acquisition and therefore expedite the language learning process.

Keywords: Scaffolding Strategy, Sight Word, English learner, Domino, team teaching, Professional Learning Community
\end{abstract}

\section{INTRODUCTION}

Reading is an important skill and it is necessary for students to master reading skill while they are at a tender age as this will help students to widen their knowledge as well as use the skill to communicate with others and also to further their studies (Royanto, 2012). Sloat, Beswick and Willms (2007) stated that failure to learn reading during primary level of schooling may result in the students being unable to read well. They added that the students' limited literacy skill will lead to poor self-esteem, lack of motivation and display of behavioral and academic problems which eventually might alienate the students from the regular curriculum.

Scaffolding is an instructional strategy whereby the teacher models the desired learning strategy or task and then gradually shifts responsibility to the students. It is similar to a construction worker who uses scaffolding in building as a means of temporary support whereby after completion of the task, it is eventually removed. However, due to the complex nature of 
scaffolding method, Pentimonti and Justice (2010) commented that teachers in the primary grades often do not use scaffolding strategies despite its obvious effectiveness to enhance students' reading ability.

This study aimed to analyze the scaffolding strategies impact towards teaching new vocabulary to enhance reading ability among low literacy year two students.

\section{LITERATURE REVIEW}

\section{Theoretical Background}

Reading is a complex matter (Ehri, 2001; Snows, Burns \& Griffin, 2006). Reading ability refers to print awareness, relationship between print and speech, text structure, phonological awareness, letter naming, writing and comprehension of written text (Hesham, 2006). Reading skills refers to the ability of the learner to pronounce words in a written text with correct phonation and comprehending what is read in the text (Nesamalar et al., 2005). Reading requires the reader to interact dynamically with the text to elicit meaning and use several kinds of knowledge such as linguistic or systemic knowledge which is acquired through bottom-up processing and also schematic knowledge which is acquired using top-bottom processing (Hesham, 2006). The written text displays letters, words, sentences and paragraph that encode meaning. Readers must use appropriate knowledge, skills and strategies to determine the meaning.

There are three models of reading: bottom-up, top-down and interactive. The bottom-up model emphasizes on print whereby the reader decode the print in the form of letters and words into text, into phonological representations to construe meaning (Nooreiny, 1998). The top-down model lets readers to guess meaning in the text by making prediction about prints and meaning based on prior knowledge. The interactive model combines bottom-up and top-down reading process whereby reading is said to happen at various levels during the interaction of the text and the mental concept of the reader. The interactive model is based on the schema theory which acknowledges the need of background knowledge to facilitate reading comprehension (Hadley, 2000). Aloqaili (2012) quoted Bos and Anders (1990) who stated that "schema theory explains how knowledge is structured in memory and how these structures influence new information". Anderson and Wilson (1986) further explained that the theory rationalizes how existing knowledge affects comprehension. The theory stresses on the interactive nature of reading whereby students must be taught of techniques to process text such as making inference, activating prior knowledge and using critical thinking (Orbea \& Villabeitia, 2010).

Reading aloud is an interactive reading process that utilizes both top-down and bottom-up reading processes. Therefore, this activity is supported with schema theory as reading itself is a cognitive process to comprehend meaning (Aloqaili, 2012).

\section{STRATEGIES AND JUSTIFICATION}

Graves and Fitzgerald (2005) stated that scaffolding is an instructional approach to assist students to become fluent reader as well as having the ability to comprehend what was read. There are two components of scaffolding: planning and implementation. In planning, the teacher must identify the needs of the students, the difficulty of the text, and the purpose of reading while in implementation, the teacher executes the lesson plan and activities spread in the before, during and after reading activities. 
Scaffolding is supported by Vygotsky's learning theory (1978) on the zone of proximal development (ZPD). This refers to the gap between what student can do independently to achieve the goal of reading and what the student is able to do with the assistance of the teacher to complete the whole task (Fitzgerald \& Graves, 2004). In scaffolding instruction, the teacher provides support to facilitate students' ability to build on prior knowledge and comprehend new information. The scaffold strategies are incorporated throughout the reading process from prereading, while-reading and post-reading activities. The teacher provides assistance and guidance to the students so that they can read, learn and respond to the text in ways they were not able to do without the scaffold or support. Teachers would continue to provide this support until the students are able to effectively read independently.

Scaffolding strategies are important and appropriate support from the teacher to help low literacy students. Salsbury (2005) describes the positive effect for pre-reading activities that develop students' background knowledge such as pre-teaching vocabularies, then followed by cooperative activities such as jigsaw reading, modified text and individual teacher-student interaction in while-reading activity and ending with post-reading activities to reinforce content and language (Echevarria, Vogt \& Short, 2004; Fitzgerald \& Graves, 2004; Rodgers, 2005).

\section{Activities Implementation Procedures}

Scaffolding can be complex strategies as there are many to choose from depending on the needs of the students, the difficulty of the reading text and the purpose of reading (Graves \& Fitzgerald, 2005). Gibbons (2005) proposed that the activity should focus on two aims: (a) to ensure that the readers understand what is read; and (b) the readers know what strategies are used with other books. The proposed implementation of scaffolding strategies during reading aloud activity is divided based on the three main phases of learning: pre-reading, while-reading and post-reading activities.

\section{Pre-Reading Activities}

In pre-reading activities, the main task of the teacher is to provide motivation to the students (Fitzgerald \& Graves, 2004). The teacher asks questions or makes statements which would pique or enhance students' interest in reading the book or reading text. The teacher can relate the reading to students' lives by providing examples of non-fiction materials to students (Mohammad Amin , 2012). Apart from that, this phase of learning should also be used to build or activate background knowledge by providing examples of scenarios. Texts that are unfamiliar should be introduced using the students' native language or in a language that they are familiar with. Games such as Sight Word Dominoes can be used to develop print awareness of particular words and improve vocabulary recognition. 


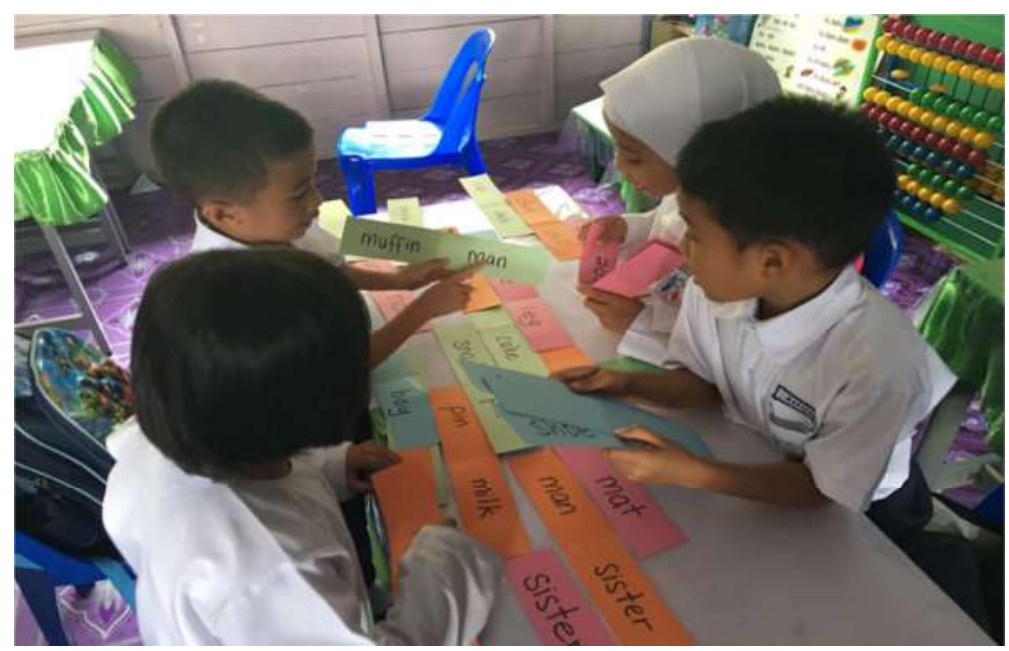

Figure 1:

Sight Word Dominoes as Pre-Reading Activities to Develop Print Awareness

\section{While-Reading Activities}

While-reading activities require the teacher to use several types of scaffolding strategies depending on the needs of the students. Pentimonti and Justice (2010) proposed six scaffolding strategies that teachers may employ which are: generalizing, reasoning, predicting, coparticipation, reducing choices and eliciting. The three strategies: generalizing, reasoning and predicting are used when the student is nearing maturation or having greater ability to read (O'Connor et al., 2005) while for students needing greater support requires the other three scaffolding strategies: eliciting, reducing choices and co-participating (Norris \& Hoffman, 1990). For the purpose of this action plan, the teachers will be provided coaching and guidance on the three scaffolding strategies: eliciting, reducing choices and co-participating. The implementation procedure includes a discussion with the teachers to understand the meaning of these strategies and how it can be practiced during reading aloud activity. Then, modeling of the strategies using students in an actual reading aloud situation will be carried out to ensure that teachers gain understanding and confidence to use these strategies effectively.

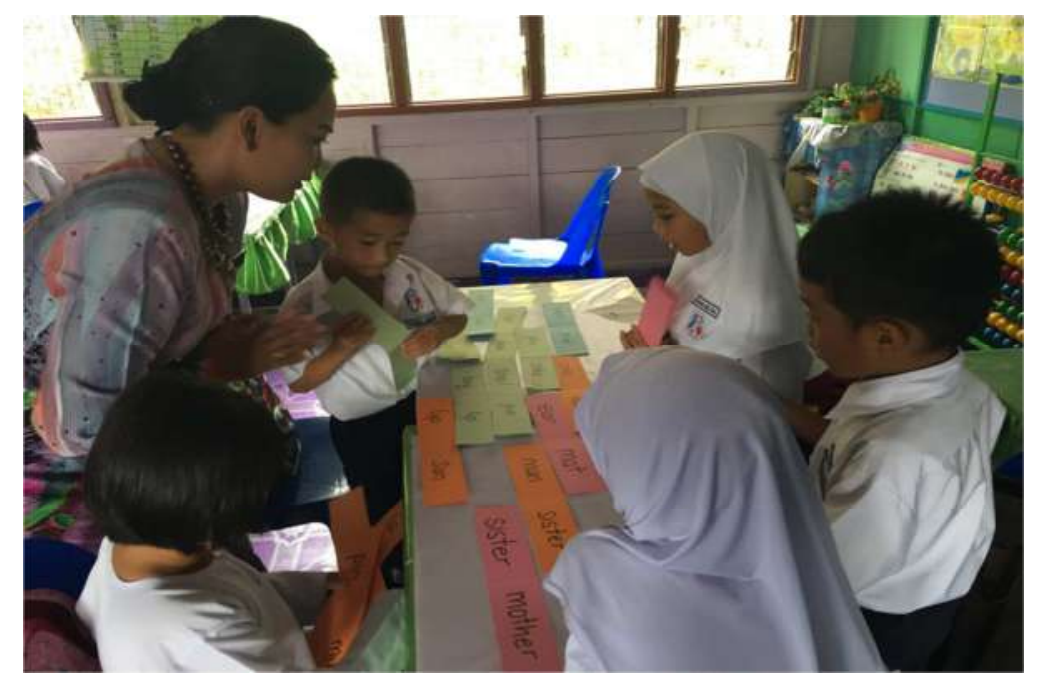

Figure 2:

Use of Scaffolding Strategies in While-Reading Activities such as Eliciting Pronunciation of Particular Syllables 


\section{Post-Reading Activities}

For the post-reading activities, the teacher uses questions verbally and brings the students into discussion about the story they have read. Discussion provides teacher with an insight whether the students understood what was read and evaluates what needs to be emphasized in future reading aloud activities. Reading aloud can be further enhanced when the post-reading activities include hands-on learning such as role playing what was read (Mohammad Amin, 2012). Other than that, I also proposed that word games such as dominoes as shown below can be used to reinforce vocabulary and print awareness from the story book or reading materials.

\section{METHODOLOGY}

\section{Research Design}

This is a descriptive quantitative research that gathers data through survey and quasi-experiment method. Quasi-experiment refers to the usage of pretest and post test to test the effectiveness of scaffolding method in teaching English. Survey method refers to the usage of interviews for students to find out their response towards scaffolding method in learning English. This research involved a group consisted of 95 primary two students of SK Selupoh, Tuaran in Sabah where the teachers were implementing scaffolding method in their teaching. Two methods of data collection were utilized for this research: the english test and interviews with the subject teachers and students.

\section{Research Sample}

This study involves three primary two classes of SK Selupoh Tuaran and the research was conducted during school period. The number of samples from each class was shown in table 3.1

Table 3.1: Research Sample

\begin{tabular}{cc}
\hline Class & Number of Students \\
\hline Class A & 33 \\
Class B & 32 \\
Class C & 30 \\
Total sample & 95 Students \\
\hline
\end{tabular}

\section{Research Instrument}

This study involves two instruments which are the (i) survey interview questionnaire and (ii) Pre/Post Test. The questionnaire was used to know students perception on Scaffolding method in learning. The result from the pre/posttest was used to measure student's performance in English.

\section{Data Collection Procedure}

The time required for data collection takes approximately 5 weeks. Students will have to answer their pre-test before their intervention session in the first week and their marks will be recorded. The intervention session will take place after the pre-test period and post test will be carried out after the end of fifth intervention or during the fifth week. Interview session will take place after students has finish their post test.

Overall, the intervention action plan can be divided into several phases of coaching and guidance as well as trials for the teachers. The following describes these phases more elaborately. 


\section{Phase One: Identification \& Selection of Trainees}

Trainees were selected for the intervention program based on several factors such as: incidence of low literacy particularly reading abilities of the students under their care; and level of motivation of the teacher to address the reading problem of their students. Once, the trainees are selected, an informal observation was conducted to determine their current scaffolding strategies used in reading aloud activities with their students.

\section{Phase Two: Discussion and Knowledge Sharing}

The teachers were led into discussion to highlight the incidence of low literacy issues of their students, to analyze current strengths and weaknesses of the reading aloud activities that they are conducting and evaluating on the scaffolding strategies they apply during the reading aloud activity. Then, the discussion also entails about the importance of using appropriate and effective strategies during reading aloud activities to enhance the effectiveness of the activity and produce able readers.

\section{Phase Three: Team Teaching Method (Professional Learning Community)}

I was personally coaching and modeling scaffolding strategies particularly the three strategies: (i) Identify issue and carry out intervention, (ii) Preparation and testing of teaching material for improvement, (iii) Implementing group teaching in class such as co-participating during mock reading aloud activity with the trainees and then practicing the strategies with actual reading aloud activity. During this phase, I expected the trainees to read more on scaffolding strategies to enhance their knowledge of the strategies and gave them room and opportunities to use these strategies in their teaching and learning activities.

\section{Phase Four: Selecting the Target Students}

Each teacher identified six students with low literacy level from their group of Year Two students to be involved in the intervention program. This is done with the approval and support from respective school management.

\section{Phase Five: Implementing the Intervention Program}

The reading aloud activity was carried out using scaffolding strategies. The same story book was be used by the teacher for three consecutive reading aloud activities to provide repeated exposure to the text. Prior to the intervention program, a pre-assessment of the students' reading ability was carried out and after the intervention program, another post-assessment was carried out to determine reading fluency, correct phonation and comprehension of the text.

\section{Phase Six: Evaluation and Further Action}

The last phase is the evaluation process whereby there was discussion with the teachers to get feedback about the intervention program. A report is also written to describe the intervention program with recommendations of future actions.

\section{DATA ANALYSIS PROCEDURE}

The data collected was analyzed using Statistical software which is the IBM SPSS 23.0. In this study, descriptive statistic method will be used to analyze students result in Pre/Post test and Inferential statistical will use T-Test with $95 \%(\alpha=0.05)$ to estimate the difference of marks between pre test and post test. 


\section{FINDINGS AND DISCUSSION}

The data collected was analyzed using Statistical software which is; the IBM SPSS 23.0. Descriptive statistical analysis determines the demographic profiles of the respondents and the levels of variables based on mean scores.

\section{Respondents Background}

Table 4.1 shows the gender and race of students in SK Selupoh Tuaran. The number of male students is higher $(53.7 \%)$ followed by female students (46.3\%). Class B has more male students and class $\mathrm{C}$ has more female students. As for racial background, the highest ethnic group is Bajau (23.3\%) followed by Chinese (15.8\%), KadazanDusun (13.7\%), other native bumiputera $(12.6 \%)$ and Malay (10.5\%).

Table 4.1: Respondent Demographic background

\begin{tabular}{lcccc}
\hline \multicolumn{1}{l}{ Demographic } & Class A & Class B & Class C & Total \\
\hline Gender & & & & \\
(a) Male & $15(45.5 \%)$ & $17(53.1 \%)$ & $19(53.7 \%)$ & $51(53.7 \%)$ \\
(b) Female & $18(54.5 \%)$ & $15(46.9 \%)$ & $11(36.7 \%)$ & $44(46.3 \%)$ \\
\hline Race/Ethnicity & & & & \\
(a) Malay & $4(12.1 \%)$ & $2(6.3 \%)$ & $4(13.3 \%)$ & $10(10.5 \%)$ \\
(b) Chinese & $6(18.2 \%)$ & $5(15.6 \%)$ & $4(13.3 \%)$ & $15(15.8 \%)$ \\
(c) Indian & $3(9.1 \%)$ & $3(9.4 \%)$ & $0(0.0 \%)$ & $6(6.3 \%)$ \\
(d) Kadazan/Dusun & $5(15.2 \%)$ & $6(18.8 \%)$ & $2(6.7 \%)$ & $13(13.7 \%)$ \\
(e) Bajau & $7(21.2 \%)$ & $4(12.5 \%)$ & $11(36.7 \%)$ & $22(23.2 \%)$ \\
(f) Brunei/Kedayan & $3(9.1 \%)$ & $3(9.4 \%)$ & $1(3.3 \%)$ & $7(7.4 \%)$ \\
(g) Murut & $1(3.0 \%)$ & $2(6.3 \%)$ & $0(0.0 \%)$ & $3(3.2 \%)$ \\
(h) Other Bumiputera & $4(12.1 \%)$ & $6(18.8 \%)$ & $2(6.7 \%)$ & $12(12.6 \%)$ \\
(i) Others & $0(0.0 \%)$ & $1(3 / 1 \%)$ & $6(20.0 \%)$ & $7(7.4 \%)$
\end{tabular}

\section{Students Perception on Scaffolding method}

Students' perception and response towards scaffolding method was shown in Diagram 4.2

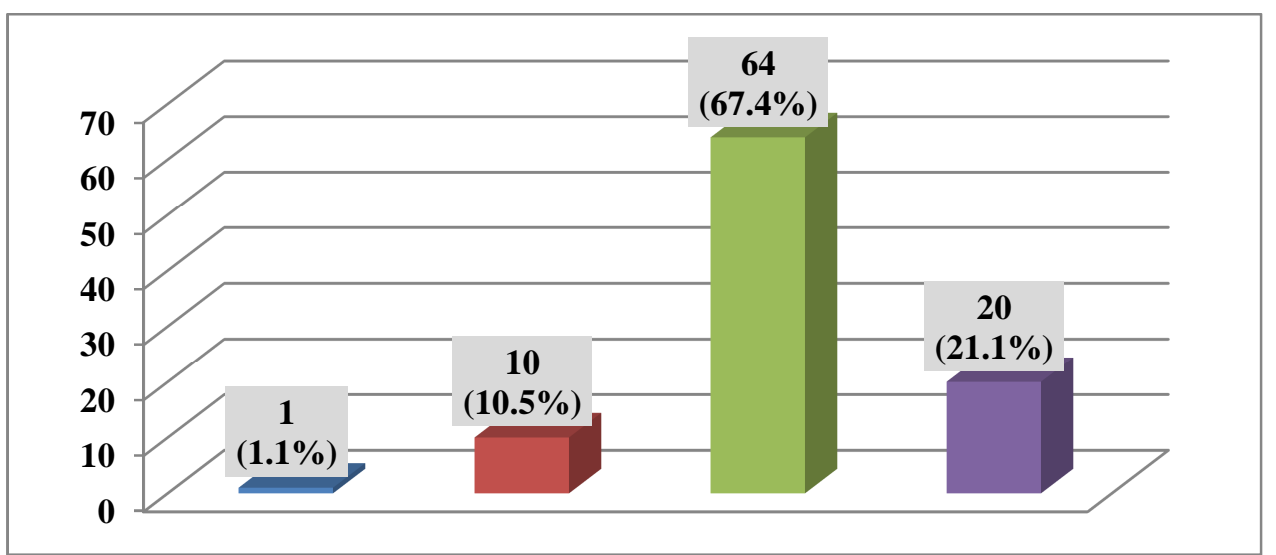

Diagram 4.2: Students Perception to Scaffolding Method (Vocabulary) 
From the survey conducted, $67.4 \%$ of students agree that their English Vocabulary improved after intervention in their English classes, $10 \%$ of students disagree that scaffolding method improved their vocabulary. The remaining $20 \%$ students did not feel any changes throughout the intervention and $1 \%$ has no comment.

\section{Students Response towards Scaffolding Activities}

Students' perception and response towards scaffolding activities conducted during the intervention was shown in Diagram 4.3.

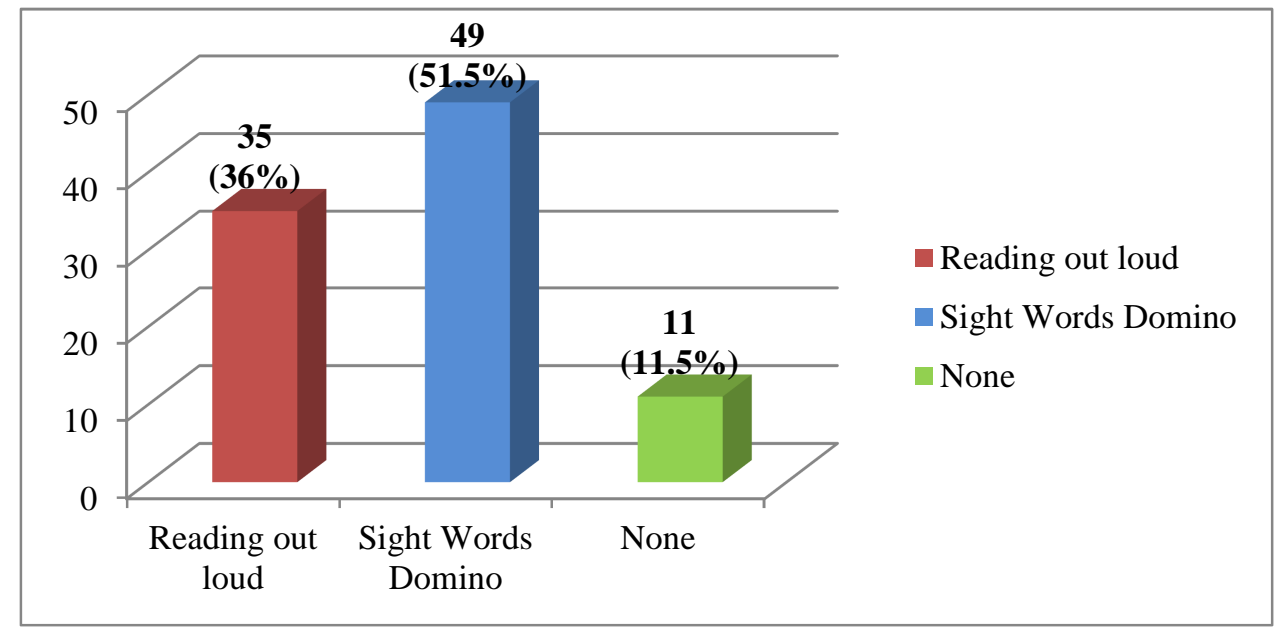

Diagram 4.3: Students response to Scaffolding Activities

From the survey conducted, 51.5\% of students enjoy having Sight words Domino method implemented in their English classes, 36\% of students enjoy reading out loud and the remaining $11 \%$ students prefer other scaffolding activity.

\section{Students Performance}

Students' performance was measured using their Pre Test and Post test result. Diagram 4.1 shows the difference of marks during pre test and post test. In a glance, the diagram shows that the mark of post test is higher compare to pre test.

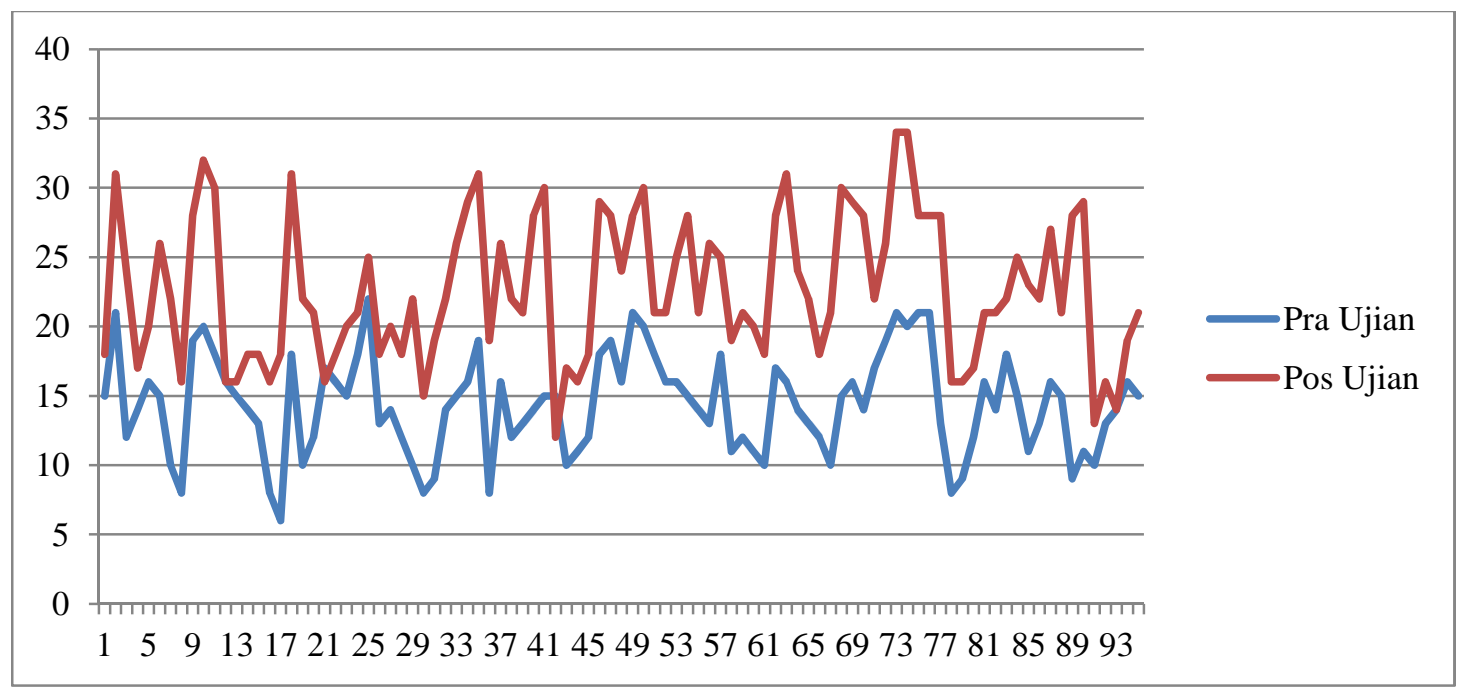

Diagram 4.1: Students Mark Comparison in Pre Test and Post Test 


\begin{tabular}{|lccccccc|}
\hline Variables & Mean & N & $\begin{array}{c}\text { Std. } \\
\text { Deviation }\end{array}$ & Correlation & $\begin{array}{c}\text { Sig. } \\
\text { Correlation }\end{array}$ & $\begin{array}{c}\text { t- } \\
\text { Value }\end{array}$ & $\begin{array}{c}\text { Sig } \\
\text { (two } \\
\text { tailed) }\end{array}$ \\
\hline Pre Test & 14.3789 & 95 & 3.60608 & \multirow{2}{*}{.599} & .000 & $\begin{array}{c}- \\
19.159\end{array}$ & 0.000 \\
\hline Post Test & 22.6842 & 95 & 5.24559 & & & & \\
\hline
\end{tabular}

Table 4.2: Result of T-Test for Pre test and Post test results

Diagram 4.1 shows that the result of post test improved after intervention session took place. This proved that there is a difference in students performance before and after intervention. Table 4.2 shows the T-test result to compare the marks from pre test and post test. The findings show that the t-value (-19.159) has 0.000 significance value. This study concludes that there is a significant difference in students performance before and after scaffolding method was implemented in their learning session. The value of correlation 0.599 proved that there is a correlation between pre test and post test result.

\section{CONCLUSION AND SUGGESTION}

This study suggests that scaffolding method in teaching and learning can help to ensure the quality of teaching language subject. By developing the competence and confidence of teacher trainees' teaching ability, this will contribute to their students' academic performance. Lange (2002) stated that scaffolding is helpful to failing children, both in terms of their cognitive development and in terms of self-efficacy and self-esteem: this result seems to support this notion. In this study, these features were measured directly, and can also be understood from the students' opinions.

Overall, I believe that not only students, but trainees have also benefitted from this intervention program. They have become more confident to try new strategies and improve their teaching and learning strategies to overcome reading weaknesses among the students. They have also become more proactive to try out other scaffolding activities and use more creative activities in their English classroom not only in reading for Year Two but also for pupils in higher class level. My personal observation showed that teachers need proper guidance and mentoring and they like it when the coach works together hand in hand with them rather than just giving instruction from afar. The rapport we developed during this intervention program helps to promote closer relationship and encourage more collaborative efforts in the future.

The present study has been conducted with a few groups of participants from the same school. It is therefore important that it is replicated within similar sample groups from other schools so that results can be verified. As with this study, future studies might work towards identifying the types of scaffolding strategies used in the teaching of english course both by practicing teachers and student teachers in whole class, small group and one-to-one environments. On the other hand, no demographic criteria were used on the selection of student teachers, although in further studies, the selection of student teachers might be made according to their beliefs about teaching and learning, their academic achievement, or their department, for example, and the research may focus on the determination of the relationship between these variables and the types of scaffolding method they have used. 


\section{REFERENCES}

Aloqailo, A. S. (2012). The relationship between reading comprehension and critical thinking: A theoretical study, Journal of King Saud University - Languages and Translation, 24, $35-41$

Allan, J. \& Bruton, A. (1998). Squeezing out the juice: Perceptions of reading in the secondary school. Available at: http:/www.scre.ac.uk /spotlight/ spotlight61.html

Anderson, R.C., Hiebert, E.H., Scott, J.A., \& Wilkinson, I.A.G. (1985). Becoming a nation of readers: The report of the Commission on Reading. Washington, DC: National Institute of Education

Beck, I.L, McKeown, M.G., \& Kucan, L. (2002). Bringing words to life: Robust vocabulary instruction. New York: Guilford.

Brabham, E.G., \& Lynch-Brown, C. (2002). Effects of teachers' reading-aloud styles on vocabulary acquisition and comprehension of students in early elementary grades. Journal of Educational Psychology, 94, 465-473

Bunn, T.K (2006). The effectiveness of additional interventions for children with literacy difficulties in Years 3 \& 4. (Unpublished Thesis), University of Warwick, Coventry CV4 7AL, United Kingdom

Central Intelligence Agency (2013). The World Factbook, Available at: https://www.cia.gov/library/publications/the-world-factbook/fields/2103.html

Chomsky, C. (1972). Stages in language development and reading exposure. Harvard Educational Review, 42, 1-33.

Curriculum Devleopment Centre (2013). English Year 1, KSSR. Kuala Lumpur: Ministry of Education

De Temple, J., \& Snow, C.E. (2003). Learning words from books. In A. van Kleeck, S.A. Stahl, \& E.B. Bauer (Eds.), On reading books to children: Parents and teachers (pp. 16-36). Mahwah, NJ: Erlbaum

Ehri, L.C. (2001). Systematic phonics instruction : Findings of the National Reading Panel. Graduate Center of the University of New York

Eskey, D. E. \& Grabe, W. (1995). Interactive models for second language reading: perspectives on instruction. In P. L. Carrell, J Devine, \& D. E. Eskey (Eds.), Interactive approaches to second language reading (pp. 223-238). New York: Cambridge University Press

Fitzgerald, J., \& Graves, M. F. (2004). Scaffolding reading experiences for English-language learners. Norwood, MA: Christopher-Gordon Publishers, Inc.

Geske, A., \& Ozola A. (2008). Factors influencing reading literacy at the primary school level. Journal Problems of Education in the 21st Century, 6, 71-77

Grabe, W. (1991). Current developments in second language reading research. TESOL Quarterly, 25/3, 375-406

Graves, M. \& Fitzgerald, J. (2005). Scaffolding reading experiences for multilingual classrooms. In G. Gilbert, \& G. Garcia (Eds.), English learners: Reaching the highest level of English literacy (pp. 96-124). Upper Saddle River, NJ: Pearson/Merrill Prentice Hall

Haak, J., Downer, J., \& Reeve, R. (2012). Home literacy exposure and early language and literacy skills in children who struggle with behaviour and attention problems. Early Education and Development 23(5), 728-747

Henderson, S. D., Many, J. E., Wellborn, H. P., \& Ward, J. (2002). How scaffolding nurtures the development of young children's literacy repertoire: Insiders' and outsiders' collaborative understandings. Reading Research and Instruction, 41(4), 309-330. 
Inderjit, S. (2014). Reading trends and improving reading skills among students in Malaysia, International Journal of Research in Social Sciences, Vol. 3, No. 5.

Kranzler, J. H., \& Floyd, R. G. (2013). Assessing intelligence in children and adolescents: A practical guide. New York: Guilford Press

Lane, H. B. \& Wright, T. L. (2007). Maximizing the effectiveness of reading aloud, International Reading Association,, 668-675

Macfarlane, A.H., Macfarlane, S., Savage, C., \& Macfarlane, A. (2012). Psychology down under: An indigenous orientation in New Zealand. International Journal Of Psychology, 47, 219-219

Merriam-Webster.com (2014). "Literate", Merriam-Webster Online Dictionary, available at: http://www.merriam-webster.com/dictionary/literate

Meyer, L.A., Wardrop, J.L., Linn, R.L., \& Hastings, C.N. (1993). Effects of ability and settings on kindergartners' reading performance. Journal of Educational Research, 86, 142-160

Mohd Nazri Latiff Azmi (2013). National Language Policy and its impacts on Second Language reading culture, Journal of International Education and Leadership, Vol. 3, Issues 1 ,Spring.

Morris , P., Lloyd, C.M., Millenky, M., Leacock, N., Raver, C.C., \& Bangser, M. (2013). Using classroom management to improve preschoolers' social and emotional skills: Final impact and implementation findings from the foundations of learning demonstration in Newark and Chicago. New York: MDRC Working Paper

Morrow, L.M., \& Gambrell, L.B. (2002). Literature-based instruction in the early years. In S.B. Neuman \& D.K. Dickinson (Eds.), Handbook of early literacy research (pp. 348-360). New York: Guilford

Nazariyah Sani \& Abdul Rahman Idris (2013). Identifying the challenges encountered by teachers in dealing with indigenous students, Malaysian Online Journal of Educational Management, October, Volume 1, Issue 3, 48-63

New Straits Times (June 12, 2012). Country's literacy rate above 93 per cent, New Straits Times, available at: http://www2.nst.com.my/nation/general/country-s-literacy-rate-above-93per-cent-1.93593

Nooreiny Maarof (1998). Assessing second language reading. Bangi: Faculty of Language Studies.

Nurul Aleena Ruman Abdullah (2006). Using whole word approach to teach reading to form one students with reading difficulties in a selected rural secondary school in Samarahan district of Sarawak, Thesis, Master of Education, Universiti Teknology Malaysia

Orbea, J. \& Villabeitia, E. (2010). The teaching of reading comprehension and metacomprehension strategies. A program implemented by teaching staff. Anales de Psicologia 26 (1), 112-122

Pentimonti, J. M. \& Justic, L. M. (2010). Teachers; use of scaffolding strategies during read alouds in the preschool classroom, Early Childhood Educ. J., 37: 241 - 248

Pressley, M., Hogan, K., Wharton-McDonald, R., Mistretta, J., \& Ettenberger, S. (1996). The challenges of instructional scaffolding: The challenges of instruction that supports student thinking. Special Issue: Constructivism and Students with Special Needs: Issues in the Classroom, 11(3), 138-146

Rasinski, T. (2013). Effective Teaching of Reading: From Phonics to Fluency. Kent, OH: Teacher Created Materials. 
Roberts, R. N., \& Barnes, M. L. (1992). "Let momma show you how”: Maternal-child interactions and their effects on children's cognitive performance. Journal of Applied Developmental Psychology, 13, 363-376.

Rodgers, E. M. (2005). Interactions that scaffold reading performance. Journal of Literacy Research, 36, 501-532.

Rogoff, B. (1990). Apprenticeship in thinking: Cognitive development in social context. New York: Oxford University Press

Royanto, L. R. M. (2012). The effect of an intervention program based on scaffolding to improve metacognitive strategies in reading: a study of Year 3 Elementary School Students in Jakarta, Procedia - Social and Behavioral Science, 69: 1601 - 1609

Salsbury, T. (2005). Scaffolding reading activities in a content-based course for students of engineering, architecture and design. The ESP World, 2(10). Available at: http://espworld.info/Articles_10/Content-based\%20Engineering.htm

Scarborough, H.S., \& Dobrich, W. (1994). On the efficacy of reading to preschoolers. Developmental Review, 14, 245-302

Sharif, I., Ozuah, P.O., Dinkevich, E.I., \& Mulvihill, M. (2003). Impact of a brief literacy intervention on urban preschoolers. Early Childhood Education Journal, 30, 177-180.

Sloat, E.A., Beswick, J.F., \&Williams, J.D. (2007) Using early literacy monitoring to prevent reading failure. Phi Delta Kappan. 88 (7) 523-529. Available at: http://ts.isil.westga.edu/login?url=http://proquest.umi.com.ts.isil.westga.edu/pqdlink?di $\mathrm{d}=1249181111 \& \mathrm{sid}=1 \& \mathrm{Fmt}=3 \&$ clientId $=30336 \& \mathrm{RQT}=309 \& \mathrm{VName}=\mathrm{PQD}$

Stahl, S.A. (2003). What do we expect storybook reading to do? How storybook reading impacts word recognition. In A. van Kleeck, S.A. Stahl, \& E.B. Bauer (Eds.), On reading books to children: Parents and teachers (pp. 363-383). Mahwah, NJ: Erlbaum.

Stanovich, K.E., Cunningham, A.E., \& West, R.F. (1998). Literacy experiences and the shaping of cognition. In S.G. Paris \& H.M. Wellman (Eds.), Global prospects for education: Development, culture, and schooling (pp. 253-288). Washington, DC: American Psychological Association

UNESCO (2004). The Plurality of Literacy and its implications for policies and programs, UNESCO Education Sector Position Paper, 13.

van Kleeck, A., Vander Woude, J., \& Hammett, L. (2006). Fostering literal and inferential language skills in Head Start preschoolers with language impairment using scripted book-sharing discussions. American Journal of Speech-Language Pathology, 15(1), 8595.

Vygotsky, L. (1978). Mind in society: The development of higher psychological processes. Cambridge, Mass.: Harvard University Press

Willingham D. \& Daniel D. (2012). Teaching to what students have in common. Educational leadership 69(5), 16-21.

Wood, D., Bruner, J. S., \& Ross, G. (1976). The role of tutoring in problem solving. Journal of Child Psychology and Psychiatry, 17(2), 89-100.

Wright J. (2012). Six reasons why students are unmotivated (and what teachers can do). The Classroom Teacher as Intervention 'First Responder': Tools for Academic Intervention and Assessment. Available at: http://www.interventioncentral.org/ccse

Yigiter K., Saricoban A. \& Gurses T. (2005). Reading strategies employed by ELT learners at the advanced level. The Reading Matrix, 5/1. Available at:http://www.readingmatrix.com/articles/saricoban/article2.pdf 
Justice, L. M., \& Ezell, H. M. (2002). Use of storybook reading to increase print awareness in atrisk children. American Journal of Speech-Language Pathology, 11, 17-29.

Price, L. H., van Kleeck, A., \& Huberty, C. J. (2009). Talk during book sharing between parents and preschool children: A comparison between storybook and expository book conditions. Reading Research Quarterly, 44, 171-194

Lynch, J., \& van den Broek, P. (2007). Understanding the glue of narrative structure: Children's on- and off-line inferences about characters' goals. Cognitive Development, 22, 323340.

Dickinson, D. K., \& Tabors, P. O. (2001). Beginning literacy with language. Baltimore, MD: Paul H. Brookes Publishing Co

Neuman, S. (1996). Children engaging in storybook reading: The influence of access to print resources, opportunity and parental interaction. Early Childhood Research Quarterly, $11,495-513$.

Sulzby, E., \& Teale, W. (1996). Emergent literacy. In R. Barr, M. L. Kamil, P. B. Mosenthal, \& P. D. Pearson (Eds.), Handbook of reading research (Vol. 2, pp. 727-757). Mahwah, NJ: Lawrence Erlbaum.

Teale, W. H. (2003). Reading aloud to young children as a classroom instructional activity: Insights from research and practice. In A. van Kleeck, A. A. Stahl, \& E. B. Bauer (Eds.), On reading books to children: Parents and teachers (pp. 114-139). Mahwah, NJ: Lawrence Erlbaum.

Walsh, B. A., \& Blewitt, P. (2006). The effect of questioning style during storybook reading on novel vocabulary acquisition of preschoolers. Early Childhood Education Journal, 33, 273-278

Morrow, L. M. (1988). Young children's responses to one-to-one story readings in school settings. Reading Research Quarterly, 23, 89-107.

Karweit, N. (1989). The effects of a story-reading program on the vocabulary and story comprehension skills of disadvantaged prekindergarten and kindergarten students. Early Education and Development, 1, 105-114

Gibbons, P. (2002) Scaffolding Language, Scaffolding Learning. Portsmouth, NH: Heinemann

Fitzgerald, J., \& Graves, M. F. (2004). Scaffolding reading experiences for English-language learners. Norwood, MA: Christopher-Gordon 